\title{
Genetic effects of polymorphisms in candidate genes and the QTL region on chicken age at first egg
}

Haiping $\mathrm{Xu}^{1 \dagger}$, Hua Zeng ${ }^{1 \dagger}$, Chenglong Luo ${ }^{2}$, Dexiang Zhang ${ }^{1}$, Qian Wang ${ }^{1}$, Liang Sun ${ }^{1}$, Lishan Yang ${ }^{1}$, Min Zhou ${ }^{3}$, Qinghua $\mathrm{Nie}^{1}$ and Xiquan Zhang ${ }^{1 *}$

\begin{abstract}
Background: The age at first egg (AFE), an important indicator for sexual maturation in female chickens, is controlled by polygenes. Based on our knowledge of reproductive physiology, 6 genes including gonadotrophin releasing hormone-I (GnRH-I), neuropeptide Y (NPY), dopamine D2 receptor (DRD2), vasoactive intestinal polypeptide (VIP), VIP receptor-1 (VIPR-1), and prolactin (PRL), were selected as candidates for influencing AFE. Additionally, the region between ADL0201 and MCW0241 of chromosome Z was chosen as the candidate QTL region according to some QTL databases. The objective of the present study was to investigate the effects of mutations in candidate genes and the QTL region on chicken AFE.

Results: Marker-trait association analysis of 8 mutations in those 6 genes in a Chinese native population found a highly significant association ( $P<0.01$ ) between G840327C of the GnRH-l gene with AFE, and it remained significant even with Bonferroni correction. Based on the results of the 2 -tailed $\chi^{2}$ test, mutations T32742394C, T32742468C, G32742603A, and C33379782T in the candidate QTL region of chromosome Z were selected for markertrait association analysis. The haplotypes of T32742394C and T32742468C were significantly associated $(P<0.05)$ with AFE. Bioinformatics analysis indicated that T32742394C and T32742468C were located in the intron region of the SH3-domain GRB2-like 2 (SH3GL2) gene, which appeared to be associated in the endocytosis and development of the oocyte.
\end{abstract}

Conclusion: This study found that G840327C of the GnRH-I gene and the haplotypes of T32742394C-T32742468C of the SH3GL2 gene were associated with the chicken AFE.

\section{Background}

Sexual maturity is a valuable index in poultry production. Although environmental factors such as body weight, body composition as well as age are critical for the onset of sexual maturity [1-4], but the trait is also determined by its genetic components. Studies of human showed that $50 \%-80 \%$ of the variation in pubertal timing is determined by genetic factors $[5,6]$. The age at first egg (AFE) is one of the direct indicators for sexual maturation in female chickens. Earlier work

\footnotetext{
* Correspondence: xqzhang@scau.edu.cn

† Contributed equally

${ }^{1}$ Department of Animal Genetics, Breeding and Reproduction, College of Animal Science, South China Agricultural University, Guangzhou 510642,

Guangdong, China

Full list of author information is available at the end of the article
}

suggested that the estimated heritability $\left(h^{2}\right)$ for AFE ranged from 0.20 to 0.56 in different strains [7-9]. Although the inheritance of AFE has been studied intensively, very little information is available concerning the molecular aspects. The development of molecular biology tools has allowed investigation of the genetic basis of AFE at the molecular level.

AFE is controlled by polygenes [10-12] and the selection of candidate genes was derived mainly from our knowledge of reproductive physiology. Sexual maturation in the chicken is the consequence of a complex cascade of progressive maturational events involving the entire hypothalamic-pituitary-gonadal axis. Gonadotrophin-releasing hormone $(\mathrm{GnRH})$ is the start of the cascade [13]. GnRH, binding with its receptor, stimulates the synthesis and secretion of gonadotrophins $[14,15]$, 
which induce steroidogenesis of the gonads, culminating in ovarian follicle growth and ovulation for egg production [16]. Neuropeptide Y (NPY) was found to be involved in the regulation of GnRH secretion via its receptor $[14,17]$ and the injection of NPY can induce precocious puberty in chicks [18]. Therefore, the GnRH$I$ and NPY genes were chosen as candidates for chicken AFE in this study. On the other hand, some workers reported that dopamine (DA) might be one of the putative neurotransmitters responsible for the activity of GnRH and had both stimulatory and inhibitory influences on gonadotropin release in birds [19-21]. Thus, one of its receptors, dopamine D2 receptor (DRD2), could be a candidate gene for the control of AFE. Kadarmideen found that prolactin (PRL) was one of the major regulators of $\mathrm{GnRH}$ and $\mathrm{GnRH}$ receptors and thus validated its important role in mammalian reproduction and sexual maturity [22]. In avian, it has been shown that exogenous PRL inhibited LH secretion by reducing $\mathrm{GnRH}$ levels in the hypothalamus, which could delay the onset of egg laying $[23,24]$. Similarly, the neurotransmitter vasoactive intestinal polypeptide (VIP) was reported to modulate GnRH neurons via VIP receptors in both mammalian and avian species $[25,26]$. Thus in this study, VIP and VIP receptor-1 (VIPR-1), as well as $P R L$ were chosen as candidates to analyze the genetic effects on chicken AFE.

To date, a number of QTL studies have been conducted in order to identify QTL affecting chicken AFE [27-29]. On the basis of some known chicken QTL databases such as http://www.animalgenome.org/cgi-bin/QTLdb/GG/ index, http://chicken.genomics.org.cn/, and http://www. thearkdb.org/arkdb/, several novel QTL affecting AFE were identified on chicken chromosomes 1,3 and $\mathrm{Z}$ [30-32]. Tuiskula-Haavisto reported that an area affecting the AFE was located on chromosome Z [28]. Another study found that the QTL region significantly linked with AFE was located between ADL0201 and MCW0241 of chromosome Z [29]. This region is used as the candidate QTL region for AFE in the present study.

The objective of this study was to identify variations that showed an association with chicken AFE in the candidate genes and the candidate QTL region. In this study, a total of 8 mutations in the GnRH-I, NPY, DRD2, VIP, $V I P R-I$, and PRL genes were chosen for marker-trait association analysis in a Chinese native chicken population. Based on two-tailed $\chi^{2}$ test method, 4 single nucleotide polymorphisms (SNPs) of the candidate QTL region were selected to analyze their associations with AFE.

\section{Methods}

\section{Chicken Population and Trait Observation}

The Ningdu Sanhuang (NDH) chicken (a Chinese native chicken population from Jiangxi province) possesses markedly early maturity. Generally, NDH males first crow at $80 \mathrm{~d}$ of age and the AFE of females is about $133 \mathrm{~d}$ of age when reared on the floor. The population used for this study was NDH female chickens from a half-sib population of Guangdong Wens Foodstuff Company Ltd, Guangdong, China, which had been kept as a closed breeding population for five generations. A total of 1, $310 \mathrm{NDH}$ female individuals from one hatch were used in association analysis. Chickens were exposed to light continuously during the first 3 days post hatch, and then to a $16 \mathrm{~h} \mathrm{light/8}$ $\mathrm{h}$ dark cycle. All individuals were fed ad libitum to 77 $\mathrm{d}$ of age with diet for $2,837 \mathrm{kcal}$ of $\mathrm{ME} / \mathrm{kg}$, and then changed to be fed with diet for 2, $907 \mathrm{kcal}$ of ME/ $\mathrm{kg}$. From $90 \mathrm{~d}$ to $300 \mathrm{~d}$ of age, all chickens were shifted into individual laying cages and the AFE trait was recorded. The average value of AFE in this population was $124.3 \pm 16.8 \mathrm{~d}$. At $300 \mathrm{~d}$ of age, the blood samples of chickens were collected from a vein under the wing of each bird and the genomic DNA was extracted. All animal procedures were performed in accordance with Law of the People's Republic of China on Animal Protection.

According to the AFE record, 24 birds with the earliest AFE and 24 individuals with the latest AFE out of $1,310 \mathrm{NDH}$ females were chosen for 2-tailed $\chi^{2}$ test in the QTL region. The mean AFE values were $92.5 \pm 1.3$ $\mathrm{d}$ in the early group and $166.4 \pm 5.9 \mathrm{~d}$ in the late group.

\section{SNP Selection and Primer Design}

The SNPs used for genotyping were obtained from two resources: (1) the variations of candidate genes for chicken AFE including the GnRH-I, NPY, DRD2, VIP, VIPR-I, and PRL genes and (2) those located within a QTL region between ADLO201 and MCW0241 (32.17 $34.26 \mathrm{Mb}$ ) on chromosome $\mathrm{Z}$.

Eight SNPs from the 6 candidate genes were selected on the basis of information in the dbSNP database http://www.ncbi.nlm.nih.gov/entrez/query.fcgi? $\mathrm{CMD}=$ search\&DB=snp and earlier reports [33-36]. Eight pairs of primers used for SNP genotyping (Table 1) were designed with Genetool software (http://www.biologysoft.com/; BioTools, Alberta, Canada).

Twelve candidate markers, including 7 from the dbSNP database http://www.ncbi.nlm.nih.gov/entrez/ query.fcgi? $\mathrm{CMD}=$ search $\& \mathrm{DB}=$ snp and $5(\mathrm{M} 9-\mathrm{M} 12$, and M20) from an earlier scan (data not shown) were selected from the candidate QTL region for 2-tailed test (Table 2). The inclusion criterion for selecting markers was that the average distance between two adjacent markers was about $200 \mathrm{~kb}$. Sites chose by 2 -tailed test method were used for the following association analysis of the QTL region. Three pairs of primers (M10 or M11, M12 and M13, Table 2) were designed and 
Table 1 Primers of mutations in the candidate genes

\begin{tabular}{|c|c|c|c|c|c|c|c|}
\hline No. & Sites $^{1}$ & $\mathrm{Chr}^{2}$ & Gene & $\begin{array}{l}\text { Primer sequence } \\
\left(5^{\prime} \rightarrow 3^{\prime}\right)\end{array}$ & Length $^{3}$ (bp) & $\mathrm{AT}^{4}\left({ }^{\circ} \mathrm{C}\right)$ & Restriction enzyme \\
\hline M1 & G840327C & Chr22 & GnRH-I & $\begin{array}{l}\text { F:tgtcacacccaggatctcaa } \\
\text { R:gctgttcagaggcacgtgag }\end{array}$ & 310 & 59.0 & Mnll \\
\hline M2 & C31394761T & Chr2 & NPY & $\begin{array}{c}\text { F:cgtggctgctttgcttcctttc } \\
\text { R:ggggtacgaggcaaggacatg }\end{array}$ & 324 & 60.0 & Kpn I \\
\hline M3 & T5841629C & Chr24 & DRD2 & $\begin{array}{l}\text { F:tgcacataaaagcccactcactg } \\
\text { R:gcctgagctggtgggggg }\end{array}$ & 248 & 60.0 & BseGl \\
\hline M4 & G51389822T & Chr3 & VIP & $\begin{array}{l}\text { F:gcttggactgatgcgtactt } \\
\text { R:gtatcactgcaaatgctctgc }\end{array}$ & 520 & 58.0 & Apo I \\
\hline M5 & A1661691G & Chr2 & VIPR-1 & $\begin{array}{c}\text { F:tgaaagcccccaggatct } \\
\text { R:agcaaaacaaaacccaaatca }\end{array}$ & 364 & 58.2 & Tai I \\
\hline M6 & C1704887T & Chr2 & VIPR-1 & $\begin{array}{l}\text { F:ccccgttaaactcagcagac } \\
\text { R:cccaaagtcccacaaggtaa }\end{array}$ & 434 & 58.2 & Hha I \\
\hline M7 & C1715301T & Chr2 & VIPR-1 & $\begin{array}{l}\text { F:ctcctcaggcagaccatcatg } \\
\text { R:cttgcacgtatccttgggtagc }\end{array}$ & 486 & 58.2 & Taq I \\
\hline M8 & 1597242100 & Chr2 & $P R L$ & $\begin{array}{l}\text { F:tttaatattggtgggtgaagagaca } \\
\text { R:atgccactgatcctcgaaaactc }\end{array}$ & $130 / 154$ & 54.0 & PCR \\
\hline
\end{tabular}

${ }^{1}$ The sites were based on the chicken genome sequences released in May, $2006 \mathrm{http}: / /$ genome.ucsc.edu/cgi-bin/hgGateway;

${ }^{2} \mathrm{Chr}$ referred to chromosome;

${ }^{3}$ Length indicated the length of PCR products;

${ }^{4} \mathrm{AT}$ referred to annealing temperature.

synthesized for genotyping these variations in the association analysis.

\section{PCR Amplification}

The PCR conditions used for amplification were as follows: $50 \mathrm{ng}$ of genomic DNA, $1 \mu \mathrm{M}$ of each primer, 200 $\mu \mathrm{M}$ dNTP, $1.5 \mathrm{mM} \mathrm{MgCl}$, $1 \times$ PCR buffer, and $1.0 \mathrm{U}$ Taq DNA polymerase (Sangon Biological Engineering Technology Company, Shanghai, China) in a final volume of $25 \mu \mathrm{L}$. The PCR were carried out on an Eppendorf Mastercycler (Eppendorf Limited, Hamburg, Germany) under the following conditions: $94^{\circ} \mathrm{C}$ for $4 \mathrm{~min}$; 35 cycles of $94^{\circ} \mathrm{C}$ for $30 \mathrm{~s}, n^{\circ} \mathrm{C}$ ( $n$ was the annealing temperature shown in Table 1 and 2) for $35 \mathrm{~s}, 72^{\circ} \mathrm{C}$ for $35 \mathrm{~s}$; and $72^{\circ} \mathrm{C}$ for $7 \mathrm{~min}$. The PCR products were separated on $1 \%(\mathrm{w} / \mathrm{v})$ agarose gel electrophoresis, stained with ethidium bromide and visualized in a TFM-40 Ultraviolet Transilluminator (UVP Company, Cambridge, UK).

Table 2 Primers for two-tailed test on the candidate QTL region of chromosome $Z$

\begin{tabular}{|c|c|c|c|c|c|}
\hline Primer & $\begin{array}{c}\text { Primers sequences } \\
\left(5^{\prime} \rightarrow 3^{\prime}\right)\end{array}$ & Location $^{1}(\mathrm{nt}) /$ Sites & Length $^{2}(\mathrm{bp})$ & $\mathrm{AT}^{3}\left({ }^{\circ} \mathrm{C}\right)$ & Restricton enzyme \\
\hline M9 & pyrosequencing & A32173403T & / & / & / \\
\hline M10 & $\begin{array}{l}\text { F:aggagctgggtgacattgtg } \\
\text { R:tggggtaaggacagcacagt }\end{array}$ & T32742394C & 721 & 58 & Msp I \\
\hline M11 & $\begin{array}{l}\text { F:aggagctgggtgacattgtg } \\
\text { R:tggggtaaggacagcacagt }\end{array}$ & T32742468C & 721 & 58 & Paul \\
\hline $\mathrm{M} 12$ & $\begin{array}{l}\text { F:tgcaagcccaggaatcatcactc } \\
\text { R:taaaactcttctttccttctaca }\end{array}$ & G32742603A & 294 & 58 & Alu I \\
\hline M13 & $\begin{array}{l}\text { F:tcttcgaacacattactcactga } \\
\text { R:ggcgttttgtgtttcttggcat }\end{array}$ & C33379782T (rs14761596) & 400 & 57 & Alu 1 \\
\hline M14 & pyrosequencing & G33610060A (rs 14761431) & / & / & / \\
\hline M15 & pyrosequencing & (ATT)7 33729521 (ATT)5 (rs16765989) & / & / & / \\
\hline M16 & pyrosequencing & C33832610T (rs14761267) & / & / & / \\
\hline M17 & pyrosequencing & G33962646T (rs16765930) & / & / & / \\
\hline M18 & pyrosequencing & C34050133T (rs14761127) & / & / & / \\
\hline M19 & pyrosequencing & C34163373T (rs16767050) & / & / & / \\
\hline M20 & pyrosequencing & G34263878A & / & / & / \\
\hline
\end{tabular}

${ }^{1}$ Location on chicken Z chromosome; ID in brackets were the refSNP ID based on the dbSNP database http://www.ncbi.nlm.nih.gov/entrez/query.fcgi? $\mathrm{CMD}=$ search\&DB=snp;

${ }^{2}$ Length indicated PCR product length;

${ }^{3} \mathrm{AT}$ referred to annealing temperature. 


\section{Genotyping of Polymorphisms}

The 12 markers of the candidate QTL region used for 2 -tailed test were genotyped by direct pyrosequencing by the Beijing Genomics Institute (BGI, Shenzhen, China).

Genotyping assays of polymorphisms used for the association analysis were based on the presence or the absence of a restriction site in the PCR-amplified DNA fragments. Genotyping of M8 was performed directly by electrophoresis in a $3.5 \%$ agarose gel after PCR amplification. The genotypes of the other sites for marker-trait association analysis were determined by PCR-RFLP method: $7 \mu \mathrm{L}$ of PCR product was digested with the corresponding restriction enzyme according to the manufacturer's protocol. Digestions were performed overnight at $37^{\circ} \mathrm{C}$ (BseGI at $55^{\circ} \mathrm{C}$, Taq I and Tai I at $65^{\circ} \mathrm{C}$ ). Subsequently, the PCR products were separated by electrophoresis in a $2.5 \%$ agarose gel and the genotypes were determined with a TFM-40 Ultraviolet Transilluminator (UVP Company, Cambridge, UK).

\section{Statistical Analyses}

Two-tailed $\chi^{2}$ Test

Comparisons of genotypes between the early and the late AFE groups were evaluated by a 2 -tailed $\chi^{2}$ test and a Bonferoni corrected $\mathrm{P}$-value threshold $(\mathrm{P}=0.05 / 12=$ 0.0042 ) was employed.

\section{Haplotype Inference}

The haplotype structure was analyzed with the Haploview v 3.32 software http://www.broad.mit.edu/mpg/ haploview/. Haplotypes were constructed with PHASE 2.0 software http://www.stat.washington.edu/stephens/ software.html on the basis of the haplotype structure.

\section{Marker-Trait Association Analysis}

Association analysis of polymorphisms or haplotypes with AFE was performed with the GLM procedures of SAS 8.0 software (SAS Institute Inc., Cary, NC, USA) using the following model:

$$
Y=\mu+G+S+e,
$$

Where $Y$ is a trait observation, $\mu$ is the overall population mean, $G$ is the effect of genotype or haplotype, $S$ is the fixed effect of sire, and $e$ is the residual error. Multiple comparisons were performed with least squares means by Fisher's least-significance difference method. The values were presented as least square means \pm standard error means. The results for the 12 markers ( 8 in the candidate genes and 4 in the QTL region) were assessed by a Bonferoni 5\% significance threshold of $\mathrm{P}=$ $0.05 / 12=0.0042$ and a Bonferoni $1 \%$ great significance threshold of $\mathrm{P}=0.01 / 12=0.00083$, conservatively assuming the 12 tests to be independent. For the haplotype block in the QTL region, the level of statistically significant difference was set at $\mathrm{P}<0.05$.

\section{Bioinformatics Analysis}

Gene mapping of the sites associated with AFE in the candidate QTL region and analysis of their function were completed by the use of 2 bioinformatic web sites of http://www.ensembl.org/Gallus_gallus/index.html and http://www.ncbi.nlm.nih.gov/mapview/.

\section{Results}

Association of Polymorphisms in the 6 Candidate Genes with Chicken AFE

Association of the 8 polymorphisms in the 6 candidate genes with chicken AFE was analyzed and the results were shown in Table 3 . A highly significant association $(\mathrm{P}<0.01)$ was found between the SNP G840327C of the chicken $G n R H-I$ gene and AFE. In addition, the mean AFE value of birds with the $C C$ genotype was great significantly higher $(\mathrm{P}<0.01)$ than that of birds with the $G C$ or $G G$ genotype. These effects remained great significant $(\mathrm{P}<0.00083)$ even after Bonferroni correction for multiple testing. Significant associations $(\mathrm{P}<0.05)$ were detected between AFE and 3 SNPs including C31394761T of the NPY gene, T5841629C of the DRD2 gene, and $A 1661691 G$ of the VIPR-1 gene. Allele $C$ of $C 31394761 T$ and allele $A$ of $A 1661691 G$ were positive for chicken AFE. However, all these significant effects disappeared when results were corrected by Bonferroni method for multiple testing (Table 3). No other site was found to be significantly associated with chicken AFE.

\section{Haplotype Structure in the VIPR-1 Gene and Their Association with AFE}

M5, M6 and M7 were all in the chicken VIPR-1 gene and haplotype structure analysis showed that there was a haplotype block composed of M6 and M7. Three haplotypes with frequencies higher than 1\%, H1 (CT, $18.91 \%), \mathrm{H} 2$ (CC, 77.69\%), and H3 (TC, 3.04\%), were observed in this block. A total of 1, $295 \mathrm{NDH}$ chickens with 6 diplotypes, including 114 of $\mathrm{H} 1 \mathrm{H} 1,249$ of $\mathrm{H} 1 \mathrm{H} 2$, 14 of $\mathrm{H} 1 \mathrm{H} 3,853$ of $\mathrm{H} 2 \mathrm{H} 2,60$ of $\mathrm{H} 2 \mathrm{H} 3$, and 5 of $\mathrm{H} 3 \mathrm{H} 3$, were used in the association analysis. However, no significant association $(P=0.3133)$ was detected between the haplotypes and chicken AFE.

\section{Association of AFE with Polymorphisms in the QTL Region of Interest in Chromosome $\mathbf{Z}$}

There were differences between the allelic frequency of T32742394C in the early and late AFE groups and differences in AFE between individuals with different alleles of C33379782T, although these differences were not significant (Table 4). T32742394C and C33379782T, 
Table 3 Association of the SNPs in the candidate genes with chicken AFE

\begin{tabular}{|c|c|c|c|c|c|c|}
\hline No. & Candidate gene & Sites $^{1}$ & Genotype & $\mathrm{N}^{2}$ & $\mathrm{AFE}^{3}$ & $P$ value \\
\hline \multirow[t]{3}{*}{ M1 } & GnRH-I & G840327C & CC & 26 & $135.1 \pm 3.2^{\mathrm{A}}$ & $0.0002^{* *}$ \\
\hline & & & GC & 208 & $121.2 \pm 1.1^{\mathrm{B}}$ & \\
\hline & & & GG & 972 & $123.6 \pm 0.5^{B}$ & \\
\hline \multirow[t]{3}{*}{ M2 } & NPY & C31394761T & $\mathrm{CC}$ & 392 & $121.5 \pm 0.8^{\mathrm{a}}$ & $0.0143^{*}$ \\
\hline & & & $\mathrm{TC}$ & 600 & $124.1 \pm 0.7^{b}$ & \\
\hline & & & $\pi$ & 214 & $125.0 \pm 1.1^{b}$ & \\
\hline \multirow[t]{3}{*}{ M3 } & DRD2 & T5841629C & CC & 1060 & $123.2 \pm 0.5^{a}$ & $0.0390^{*}$ \\
\hline & & & $\mathrm{TC}$ & 217 & $126.2 \pm 1.1^{\mathrm{b}}$ & \\
\hline & & & $\pi$ & 5 & $119.2 \pm 7.4^{\mathrm{ab}}$ & \\
\hline \multirow[t]{3}{*}{ M4 } & VIP & G51389822T & GG & 74 & $123.6 \pm 1.9$ & 0.3271 \\
\hline & & & GT & 400 & $124.4 \pm 0.8$ & \\
\hline & & & $\Pi$ & 732 & $122.8 \pm 0.6$ & \\
\hline \multirow[t]{3}{*}{ M5 } & VIPR-1 & A1661691G & GG & 1028 & $123.9 \pm 0.5^{a}$ & $0.0390^{*}$ \\
\hline & & & GA & 95 & $121.4 \pm 1.7^{\mathrm{ab}}$ & \\
\hline & & & $\mathrm{AA}$ & 83 & $119.7 \pm 1.8^{b}$ & \\
\hline \multirow[t]{3}{*}{ M6 } & VIPR-1 & C1704887T & CC & 1128 & $123.2 \pm 0.5$ & 0.2022 \\
\hline & & & TC & 72 & $125.7 \pm 2.0$ & \\
\hline & & & $\pi$ & 6 & $132.0 \pm 6.7$ & \\
\hline \multirow[t]{3}{*}{ M7 } & VIPR-1 & C1715301T & CC & 842 & $123.9 \pm 0.6$ & 0.2648 \\
\hline & & & TC & 252 & $122.1 \pm 1.0$ & \\
\hline & & & $\pi$ & 112 & $122.6 \pm 1.6$ & \\
\hline \multirow[t]{3}{*}{ M8 } & $P R L$ & 1597242100 & $\|$ & 10 & $126.2 \pm 5.2$ & 0.1851 \\
\hline & & & ID & 187 & $121.4 \pm 1.2$ & \\
\hline & & & $\mathrm{DD}$ & 1009 & $123.7 \pm 0.5$ & \\
\hline
\end{tabular}

${ }^{1}$ The sites were referred to the chicken genome sequences released in May, 2006 http://genome.ucsc.edu/cgi-bin/hgGateway;

${ }^{2} \mathrm{~N}$ indicated the number of tested chickens of each genotype;

${ }^{3} \mathrm{AFE}=$ age at first egg, the values are least-square means \pm standard errors (SE).

${ }^{a, b}$ Within a column, for each site, measurements with no common superscripts are significantly different in single marker analysis, but not significantly different after Bonferroni correction $(0.0042<\mathrm{P}<0.05)$;

${ }^{\mathrm{A}, \mathrm{B}}$ Within a column, for each site, measurements with no common superscripts are great significantly different $(\mathrm{P}<0.00083) ;{ }^{*}$ and ${ }^{* *}$ indicate $0.0042<\mathrm{P}<0.05$ and $P<0.00083$, respectively.

which might be associated with AFE, were chosen for the following association analysis. In addition, sites T32742468C and G32742603A were selected as the controls.

Based on the results of the 2-tailed $\chi^{2}$ test, SNPs T32742394C, T32742468C, G32742603A, and C33379782T were chosen for marker-trait association analysis in 1, $310 \mathrm{NDH}$ individuals. As summarized in Table 5, T32742394C was significantly associated $(\mathrm{P}<$ 0.05) with chicken AFE, and birds with the $C$ genotype had earlier AFE than those with the $T$ genotype. However, these significant effects disappeared after Bonferroni correction. No significant association with AFE was found for the other SNPs.

\section{Haplotype Structure within the 4 SNPs and Their Association with AFE}

A haplotype block of T32742394C and T32742468C was observed in the NDH population for the 4 SNPs in the QTL region of chromosome Z. Four haplotypes with frequencies higher than $1 \%, \mathrm{H} 1(T C, 33.48 \%), \mathrm{H} 2$ ( $T T$, 29.84\%), H3 (CC, 2.01\%), and H4 (CT, 34.67\%), were found in this block. A total of 1, 296 chickens with 7 diplotypes, including 432 of $\mathrm{H} 1 \mathrm{H} 1,1$ of $\mathrm{H} 1 \mathrm{H} 2,1$ of $\mathrm{H} 1 \mathrm{H} 4,385$ of $\mathrm{H} 2 \mathrm{H} 2,1$ of $\mathrm{H} 2 \mathrm{H} 4,26$ of $\mathrm{H} 3 \mathrm{H} 3$, and 450 of $\mathrm{H} 4 \mathrm{H} 4$, were used in association analysis and significant association $(\mathrm{P}<0.05)$ of the haplotypes with AFE was observed (Table 6). Among the 7 diplotypes, $\mathrm{H} 1 \mathrm{H} 4$ had a significantly later $(\mathrm{P}<0.05)$ mean value of AFE (158.0 d) compared to the other diplotypes, except $\mathrm{H} 1 \mathrm{H} 2$. Furthermore, $\mathrm{H} 4 \mathrm{H} 4$ had a much earlier mean value of AFE (122.2 d) and was significantly different (P $<0.05$ ) from that of $\mathrm{H} 2 \mathrm{H} 2$.

\section{Bioinformatics Analyses}

The roles of most of the 22 functional genes within the QTL region are not known. Based on database Ensembl http://www.ensembl.org/Gallus_gallus/index.html, T32742394C related to AFE is located in the intron region of the SH3-domain GRB2-like 2 (SH3GL2) gene. 
Table 4 Allelic frequency in early and late AFE groups

\begin{tabular}{|c|c|c|c|c|c|}
\hline Location $^{1}$ & Allele & Early $^{2}$ & Late $^{2}$ & Chi square & $P$ value \\
\hline \multirow[t]{2}{*}{32173403} & A & $20(0.883)$ & $22(0.917)$ & 0.762 & 0.3827 \\
\hline & $\mathrm{T}$ & $4(0.167)$ & $2(0.083)$ & & \\
\hline \multirow[t]{2}{*}{32742394} & C & $14(0.583)$ & $8(0.333)$ & 3.020 & 0.0822 \\
\hline & $\mathrm{T}$ & $10(0.417)$ & $16(0.667)$ & & \\
\hline \multirow[t]{2}{*}{32742468} & C & $6(0.250)$ & $8(0.333)$ & 0.400 & 0.5271 \\
\hline & $\mathrm{T}$ & $18(0.750)$ & $16(0.667)$ & & \\
\hline \multirow[t]{2}{*}{32742603} & G & $17(0.708)$ & $16(0.667)$ & 0.100 & 0.7518 \\
\hline & A & 7 (0.292) & $8(0.333)$ & & \\
\hline \multirow[t]{2}{*}{33379782} & $C$ & $1(0.042)$ & $5(0.208)$ & 3.048 & 0.0809 \\
\hline & $\mathrm{T}$ & $23(0.958)$ & $19(0.792)$ & & \\
\hline \multirow[t]{2}{*}{33610060} & G & $12(0.500)$ & $11(0.458)$ & 0.083 & 0.7733 \\
\hline & A & $12(0.500)$ & $13(0.542)$ & & \\
\hline \multirow[t]{2}{*}{33729521} & (ATT)7 & $24(1.000)$ & $21(0.875)$ & 3.200 & 0.0736 \\
\hline & (ATT)5 & $0(0.000)$ & $3(0.125)$ & & \\
\hline \multirow[t]{2}{*}{33832610} & C & $1(0.042)$ & $0(0.000)$ & 1.021 & 0.3123 \\
\hline & $\mathrm{T}$ & $23(0.958)$ & $24(1.000)$ & & \\
\hline \multirow[t]{2}{*}{33962646} & $\mathrm{~T}$ & $7(0.292)$ & $5(0.208)$ & 0.444 & 0.5052 \\
\hline & G & $17(0.708)$ & $19(0.792)$ & & \\
\hline \multirow[t]{2}{*}{34050133} & C & $24(1.000)$ & $22(0.917)$ & 2.087 & 0.1486 \\
\hline & $T$ & $0(0.000)$ & $2(0.083)$ & & \\
\hline \multirow[t]{2}{*}{34163373} & C & $4(0.167)$ & $3(0.125)$ & 0.167 & 0.6828 \\
\hline & $\mathrm{T}$ & $20(0.833)$ & $21(0.875)$ & & \\
\hline \multirow[t]{2}{*}{34263878} & A & $12(0.500)$ & $13(0.542)$ & 0.083 & 0.7733 \\
\hline & G & $12(0.500)$ & $11(0.458)$ & & \\
\hline
\end{tabular}

'Location indicated the location on the $\mathrm{Z}$ chromosome;

${ }^{2}$ Number of chickens for each tail, number in brackets indicated the allelic frequency of each tail in the two-tail samples. A P-value $<0.0042$ was considered significant.

Table 5 Association of the 4 SNPs in the candidate QTL region with chicken AFE

\begin{tabular}{cccccc}
\hline No. & Location $^{1}$ & Genotype & $\mathbf{N}^{\mathbf{2}}$ & AFE $^{\mathbf{3}}$ & P value \\
\hline M10 & T32742394C & $\mathrm{C}$ & 415 & $122.2 \pm 0.8^{\mathrm{a}}$ & $0.0165^{*}$ \\
& & $\mathrm{~T}$ & 797 & $124.5 \pm 0.6^{\mathrm{b}}$ & \\
M11 & T32742468C & $\mathrm{C}$ & 443 & $124.2 \pm 0.8$ & 0.4324 \\
& & $\mathrm{~T}$ & 769 & $123.5 \pm 0.6$ & \\
M12 & G32742603A & $\mathrm{A}$ & 400 & $124.4 \pm 0.8$ & 0.3422 \\
& & $\mathrm{G}$ & 812 & $123.4 \pm 0.6$ & \\
M13 & C33379782T & $\mathrm{C}$ & 102 & $125.5 \pm 1.6$ & 0.2568 \\
& & $\mathrm{~T}$ & 1110 & $123.6 \pm 0.5$ & \\
\hline
\end{tabular}

${ }^{1}$ The sites were referred to the location on the $\mathrm{Z}$ chromosome of the chicken genome sequences released in May, 2006 http://genome.ucsc.edu/cgi-bin/ hgGateway;

${ }^{2} \mathrm{~N}$ indicated the number of tested chickens of each genotype;

${ }^{3} \mathrm{AFE}=$ age at first egg, the values are least-square means \pm standard errors (SE).

a,b Within a column, for each site, measurements with no common superscripts are significantly different in single marker analysis, but not significantly different after Bonferroni correction $(0.0042<\mathrm{P}<0.05)$; *indicate $0.0042<\mathrm{P}$ $<0.05$.
T32742468C, which formed the haplotype block with T32742394C and then affected the AFE value, is also located in intron 1 of the chicken SH3GL2 gene.

\section{Discussion}

Recently, there were many studies seeking correlations between markers of candidate genes and chicken AFE [37-39]. Although a large number of statistically significant associations were found out as assessed by a single marker analysis model in those studies, few of them were still significant while proper correction was made to reduce the false discovery rate. In this study, GnRH-I, NPY, DRD2, VIP, VIPR-1 and PRL were selected to undertake association analysis in an NDH population and 3 significant effects $(\mathrm{P}<0.05)$ on chicken AFE were observed in single analysis: for C31394761T of the NPY gene, T5841629C of the DRD2 gene, and A1661691G of the VIPR-1 gene. However, like most of previous studies, those 3 significant effects disappeared after Bonferroni correction for multiple testing. Bonferroni correction, adjusting the Type 1 error by the total number of tests, is a simple method to control the false discovery rate based on the assumption that all the tests are independent [40]. However, it is known that SNPs in close proximity are not independent [41]. Therefore, there may be some overcorrection to employ the Bonferroni adjusted significance thresholds for multiple testing in the present study. In mammalian and avian species, the important role of NPY on the sexual maturation process has been reported [42-44]. Dunn [13] found that a 4-bp indel about 700 bases upstream of the NPY gene transcription start site had a significant dominant effect on broiler AFE, and heterozygous individuals had an earlier AFE. Although a different mutation site was analyzed in this study, the NPY gene was also proved to be important for chicken AFE. In an earlier study, no significant association was observed between any mutations in the coding region of the dopamine D1 receptor (DRD1) gene and AFE [45]. Therefore, another dopamine receptor, $D R D 2$, was chosen as the candidate for AFE in this study and the results showed that it was related with this trait. Additionally, an investigation completed by our groups in a different NDH population demonstrated that $A 1661691 G$ of the VIPR-1 gene was associated with AFE [46], which was also observed in the current study. In the present study, the most notable effect on AFE in candidate genes was for the GnRH-I gene. The association between $G 840327 \mathrm{C}$ of the GnRH-I gene and AFE was consistently significant even with Bonferroni correction for multiple testing. In human, GnRH-I were mainly expressed in the hypothalamus and various compartments of ovary [47]. Some recent studies of human have 
Table 6 Association of the haplotypes in the QTL region with AFE

\begin{tabular}{|c|c|c|c|c|c|c|c|c|}
\hline Trait $^{1}$ & $P$ value & $\mathrm{H} 1 \mathrm{H}^{2}{ }^{2}$ (432) & $\mathrm{H} 1 \mathrm{H} 2^{2}(1)$ & $\mathrm{H} 1 \mathrm{H} 4^{2}(1)$ & $\mathrm{H} 2 \mathrm{H} 2^{2}$ (385) & $\mathrm{H} 2 \mathrm{H} 4^{2}(1)$ & $\mathrm{H}_{3} \mathrm{H}^{2}{ }^{2}(26)$ & $\mathrm{H} 4 \mathrm{H} 4^{2}(450)$ \\
\hline AFE & $0.0289^{*}$ & $124.2 \pm 0.8^{b c}$ & $154.0 \pm 16.5^{\mathrm{abc}}$ & $158.0 \pm 16.6^{a}$ & $124.7 \pm 0.8^{b}$ & $111.0 \pm 16.5^{b c}$ & $122.2 \pm 3.2^{b c}$ & $122.2 \pm 0.8^{c}$ \\
\hline
\end{tabular}

reported homozygous frameshift mutations in the GnRH-I gene might cause normosmic idiopathic hypogonadotropic hypogonadism in subjects displaying delayed puberty $[48,49]$. In zebra finch, Ubuka and Bentley demonstrated that GnRH-I mRNA signal was significantly increased in sexually mature birds and the ovary mass was correlated with the brain GnRH-I mRNA level [50]. In the current study, we have also shown that a marker in the GnRH-1 gene is associated with AFE in NDH chickens.

In the present study, four variations among many sites in the candidate QTL region were chosen for the following association analysis through two-tailed $\chi^{2}$ test method. Subsequently, T32742394C of chromosome $\mathrm{Z}$ was found to be associated with AFE, although the significant effect disappeared after Bonferroni correction. Results of haplotype analysis also showed that it was related to AFE. In the same way, Sutter [51] proved that a single insulin-like growth factor 1 allele was the major determinant of small size in dogs and $\mathrm{Xu}$ [35] identified the polymorphism $T+619 C$ of the DRD2 gene associated with duration of chicken broodiness. Through bioinformatics analysis, T32742394C and $T 32742468 C$ were found to be located in the intron region of the SH3GL2 gene. SH3GL2, also known as SH3P4 or endophilin I, is a gene encoding the 353 amino acids of a protein that belongs to the endophilin family. Earlier studies showed that SH3GL2 was correlated with the regulation of synaptic vesicle endocytosis in mammals [52,53]. In avian, Hirayama reported that the endophilin family was involved in oocyte endocytosis and development [54]. Therefore, it seemed that the SH3GL2 gene is associated with AFE in NDH chickens and the haplotypes of T32742394CT32742468C might play an important role in AFE. However, the genetic effects of the SH3GL2 gene on AFE require further study.

\section{Conclusions}

In conclusion, the main genetic effects of genes were analyzed in this study and the results demonstrated that the SNP G840327C of the GnRH-I gene and the haplotypes of T32742394C-T32742468C of the SH3GL2 gene were associated with the chicken AFE. These results can provide some insight into the genetics of chicken AFE.

\section{Acknowledgements and Funding}

The current work was funded by projects under the Major State Basic Research Development Program China, project No. 2006CB102107 and the earmarked fund for Modern Agro-industry Technology Research System, project No. nycytx-42-G1-04. It was also supported by the National High Technology Research and Development Program of China (863 Program), project No. 2010AA10A102 and the Science and Technology Program of Jiangxi Education Department, project No. GJJ09383.

\section{Author details}

${ }^{1}$ Department of Animal Genetics, Breeding and Reproduction, College of Animal Science, South China Agricultural University, Guangzhou 510642, Guangdong, China. ${ }^{2}$ Institute of Animal Science, Guangdong Academy of Agricultural Sciences, Guangzhou 510640, Guangdong, China.

${ }^{3}$ Biotechnology Institute, Jiang Xi Education College, Nanchang 330029, Jiangxi, China.

\section{Authors' contributions}

HX carried out the SNP genotyping of the Z chromosome, analyzed the data and drafted the manuscript. HZ and QW contributed to the SNP genotyping of the candidate genes. DZ and MZ contributed to materials collection. CL, LS and LY participated in the data analyses. QN and XZ contributed to the design of the study, the supervision of the study and the revision of this manuscript. All authors read and approved the final manuscript.

Received: 25 October 2010 Accepted: 15 April 2011

Published: 15 April 2011

\section{References}

1. Brody T, Eitan Y, Soller M, Nir I, Nitsan Z: Compensatory growth and sexual maturity in broiler females reared under severe food restriction from day of hatching. Br Poult Sci 1980, 21:437-446.

2. Zelenka DJ, Cherry JA, Nir I, Siegel PB: Body weight and composition of Japanese quail (Coturnix coturnix japonica) at sexual maturity. Growth 1984, 48:16-28.

3. Gous RM, Bradford GD, Johnson SA, Morris TR: Effect of age of release from light or food restriction on age at sexual maturity and egg production of laying pullets. Br Poult Sci 2000, 41:263-271.

4. Ciacciariello M, Gous RM: A comparison of the effects of feeding treatments and lighting on age at first egg and subsequent laying performance and carcase composition of broiler breeder hens. Br Poult Sci 2005, 46:246-254

5. Palmert MR, Boepple PA: Variation in the timing of puberty: clinical spectrum and genetic investigation. J Clin Endocrinol Metab 2001, 86:2364-2368.

6. Gajdos ZK, Henderson KD, Hirschhorn JN, Palmert MR: Genetic determinants of pubertal timing in the general population. Mol Cell Endocrinol 2010, 324:21-29.

7. Chen CF, Tixier-Boichard M: Correlated responses to long-term selection for clutch length in dwarf brown-egg layers carrying or not carrying the naked neck gene. Poult Sci 2003, 82:709-720.

8. Hu YH, Poivey JP, Rouvier R, Liu SC, Tai C: Heritabilities and genetic correlations of laying performance in Muscovy ducks selected in Taiwan. Br Poult Sci 2004, 45:180-185.

9. Lwelamira J, Kifaro GC, Gwakisa PS: Genetic parameters for body weights, egg traits and antibody response against Newcastle Disease Virus (NDV) vaccine among two Tanzania chicken ecotypes. Trop Anim Health Prod 2009, 41:51-59. 
10. Huhtaniemi I: Mutations along the pituitary-gonadal axis affecting sexual maturation: novel information from transgenic and knockout mice. Mol Cell Endocrinol 2006, 254-255:84-90.

11. Parent AS, Matagne V, Westphal M, Heger S, Ojeda S, Jung H: Gene expression profiling of hypothalamic hamartomas: a search for genes associated with central precocious puberty. Horm Res 2008, 69:114-123.

12. Feng $T$, Zhao $Y Z$, Chu MX, Zhang YJ, Fang L, Di R, Cao GL, Li N: Association between sexual precocity and alleles of KISS-1 and GPR54 genes in goats. Anim Biotechnol 2009, 20:172-176.

13. Dunn IC, Miao YW, Morris A, Romanov MN, Wilson PW, Waddington D: A study of association between genetic markers in candidate genes and reproductive traits in one generation of a commercial broiler breeder hen population. Heredity 2004, 92:128-134.

14. Pau KY, Spies HG: Neuroendocrine signals in the regulation of gonadotropin-releasing hormone secretion. Chin J Physiol 1997, 40:181-196.

15. Proudman JA, Scanes CG, Johannsen SA, Berghman LR, Camp MJ: Comparison of the ability of the three endogenous $\mathrm{GnRH}$ s to stimulate release of follicle-stimulating hormone and luteinizing hormone in chickens. Domest Anim Endocrinol 2006, 31:141-153.

16. Onagbesan OM, Metayer S, Tona K, Williams J, Decuypere E, Bruggeman V: Effects of genotype and feed allowance on plasma luteinizing hormones, follicle-stimulating hormones, progesterone, estradiol levels, follicle differentiation, and egg production rates of broiler breeder hens. Poult Sci 2006, 85:1245-1258.

17. Klenke U, Constantin S, Wray S: Neuropeptide $Y$ directly inhibits neuronal activity in a subpopulation of gonadotropin-releasing hormone-1 neurons via Y1 receptors. Endocrinology 2010, 151:2736-2746.

18. Fraley GS, Kuenzel WJ: Precocious puberty in chicks (Gallus domesticus) induced by central injections of neuropeptide Y. Life Sci 1993, 52:1649-1656.

19. Davison BA, Kuenzel WJ: Hypothalamic biogenic amine levels in broiler chicks showing advanced sexual maturation. Poult Sci 1991, 70:1610-1618.

20. Al-Zailaie KA, Kang SW, Youngren OM, Thayananuphat A, Bakken T, Chaiseha Y, Millam JR, Proudman JA, El Halawani ME: Identification of dopamine, gonadotrophin-releasing hormone-l, and vasoactive intestinal peptide neurones activated by electrical stimulation to the medial preoptic area of the turkey hypothalamus: a potential reproductive neuroendocrine circuit. J Neuroendocrinol 2006, 18:514-525.

21. Thayananuphat A, Kang SW, Bakken T, Millam JR, El Halawani ME: Rhythmic dependent light induction of gonadotrophin-releasing hormone-I expression and activation of dopaminergic neurones within the premammillary nucleus of the turkey hypothalamus. J Neuroendocrinol 2007, 19:399-406.

22. Kadarmideen HN: Genetical systems biology in livestock: application to gonadotrophin releasing hormone and reproduction. IET Syst Biol 2008, 2:423-441.

23. el Halawani ME, Silsby JL, Youngren OM, Phillips RE: Exogenous prolactin delays photo-induced sexual maturity and suppresses ovariectomyinduced luteinizing hormone secretion in the turkey (Meleagris gallopavo). Biol Reprod 1991, 44:420-424.

24. Rozenboim I, Tabibzadeh C, Silsby JL, el Halawani ME: Effect of ovine prolactin administration on hypothalamic vasoactive intestinal peptide (VIP), gonadotropin releasing hormone I and II content, and anterior pituitary VIP receptors in laying turkey hens. Biol Reprod 1993, 48:1246-1250.

25. Christian CA, Moenter SM: Vasoactive intestinal polypeptide can excite gonadotropin-releasing hormone neurons in a manner dependent on estradiol and gated by time of day. Endocrinology 2008, 149:3130-3136.

26. Li H, Kuenzel WJ: A possible neural cascade involving the photoneuroendocrine system (PNES) responsible for regulating gonadal development in an avian species, Gallus gallus. Brain Res Bull 2008, 76:586-596.

27. Schütz K, Kerje S, Carlborg O, Jacobsson L, Andersson L, Jensen P: QTL analysis of a red junglefowl $\times$ White Leghorn intercross reveals trade-off in resource allocation between behavior and production traits. Behav Genet 2002, 32:423-433.

28. Tuiskula-Haavisto M, Honkatukia M, Vilkki J, de Koning DJ, Schulman NF, Mäki-Tanila A: Mapping of quantitative trait loci affecting quality and production traits in egg layers. Poult Sci 2002, 81:919-927.
29. Sasaki O, Odawara S, Takahashi H, Nirasawa K, Oyamada Y, Yamamoto R, Ishii K, Nagamine Y, Takeda H, Kobayashi E, Furukawa T: Genetic mapping of quantitative trait loci affecting body weight, egg character and egg production in F2 intercross chickens. Anim Genet 2004, 35:188-194.

30. Schmid M, Nanda I, Hoehn H, Schartl M, Haaf T, Buerstedde JM, Arakawa H, Caldwell RB, Weigend S, Burt DW, Smith J, Griffin DK, Masabanda JS, Groenen MA, Crooijmans RP, Vignal A, Fillon V, Morisson M, Pitel F, Vignoles M, Garrigues A, Gellin J, Rodionov AV, Galkina SA, Lukina NA, BenAri G, Blum S, Hillel J, Twito T, Lavi U, David L, Feldman MW, Delany ME, Conley CA, Fowler VM, Hedges SB, Godbout R, Katyal S, Smith C, Hudson Q, Sinclair A, Mizuno S: Second report on chicken genes and chromosomes 2005. Cytogenet Genome Res 2005, 109:415-479.

31. Wang J, He X, Ruan J, Dai M, Chen J, Zhang Y, Hu Y, Ye C, Li S, Cong L, Fang L, Liu B, Li S, Wang J, Burt DW, Wong GK, Yu J, Yang H, Wang J: ChickVD: a sequence variation database for the chicken genome. Nucleic Acids Res 2005, 33:D438-441.

32. Hu ZL, Fritz ER, Reecy JM: AnimalQTLdb: a livestock QTL database tool set for positional QTL information mining and beyond. Nucleic Acids Res 2007, 35:D604-609.

33. Cui JX, Du HL, Liang Y, Deng XM, Li N, Zhang XQ: Association of polymorphisms in the promoter region of chicken prolactin with egg production. Poult Sci 2006, 85:26-31.

34. Zhou M, Lei M, Rao Y, Nie Q, Zeng H, Xia M, Liang F, Zhang D, Zhang X: Polymorphisms of vasoactive intestinal peptide receptor-1 gene and their genetic effects on broodiness in chickens. Poult Sci 2008, 87:893-903.

35. Xu HP, Shen $X$, Zhou M, Luo $C L$, Kang L, Liang $Y$, Zeng $H$, Nie $Q H$, Zhang DX, Zhang $X \mathrm{Q}$ : The dopamine $\mathrm{D} 2$ receptor gene polymorphisms associated with chicken broodiness. Poult Sci 2010, 89:428-438.

36. Zhou M, Du Y, Nie Q, Liang Y, Luo C, Zeng H, Zhang X: Associations between polymorphisms in the chicken VIP gene, egg production and broody traits. Br Poult Sci 2010, 51:195-203.

37. Feng XP, Kuhnlein U, Aggrey SE, Gavora JS, Zadworny D: Trait association of genetic markers in the growth hormone and the growth hormone receptor gene in a White Leghorn strain. Poult Sci 1997, 76:1770-1775.

38. Ou JT, Tang SQ, Sun DX, Zhang Y: Polymorphisms of three neuroendocrine-correlated genes associated with growth and reproductive traits in the chicken. Poult Sci 2009, 88:722-727.

39. Liu WJ, Sun DX, Yu Y, Li G, Tang SQ, Zhang Y, Wang YC, Zhang Y: Association of Janus kinase 2 polymorphisms with growth and reproduction traits in chickens. Poult Sci 2010, 89:2573-2579.

40. Duggal P, Gillanders EM, Holmes TN, Bailey-Wilson JE: Establishing an adjusted $\mathrm{p}$-value threshold to control the family-wide type 1 error in genome wide association studies. BMC Genomics 2008, 9:516.

41. Nicodemus KK, Liu W, Chase GA, Tsai YY, Fallin MD: Comparison of type I error for multiple test corrections in large single-nucleotide polymorphism studies using principal components versus haplotype blocking algorithms. BMC Genet 2005, 6(Suppl 1):S78.

42. Gruaz NM, Pierroz DD, Rohner-Jeanrenaud F, Sizonenko PC, Aubert ML: Evidence that neuropeptide $Y$ could represent a neuroendocrine inhibitor of sexual maturation in unfavorable metabolic conditions in the rat. Endocrinology 1993, 133:1891-1894.

43. Kuenzel WJ, Fraley GS: Neuropeptide Y: its role in the neural regulation of reproductive function and food intake in avian and mammalian species. Poult Avian Biol Rev 1995, 6:185-209.

44. Walsh KM, Kuenzel WJ: Effect of sulfamethazine on sexual precocity and neuropeptide $Y$ neurons within the tuberoinfundibular region of the chick brain. Brain Res Bull 1997, 44:707-713.

45. Xu H, Shen X, Zhou M, Fang M, Zeng H, Nie Q, Zhang X: The genetic effects of the dopamine D1 receptor gene on chicken egg production and broodiness traits. BMC Genet 2010, 11:17.

46. Zhou M, Liang F, Rao Y, Zeng H, Zhang D, Zhang X: Association of twelve polymorphisms of the VIPR-1 gene with chicken early egg production traits. Chinese Journal of Animal and Veterinary Sciences 2008, 39:1147-1152.

47. Metallinou C, Asimakopoulos B, Schröer A, Nikolettos N: Gonadotropinreleasing hormone in the ovary. Reprod Sci 2007, 14:737-749.

48. Chan YM, de Guillebon A, Lang-Muritano M, Plummer L, Cerrato F, Tsiaras S, Gaspert A, Lavoie HB, Wu CH, Crowley WF Jr, Amory JK, Pitteloud N, Seminara SB: GNRH1 mutations in patients with idiopathic hypogonadotropic hypogonadism. Proc Natl Acad Sci USA 2009, 106:11703-11708. 
49. Silveira LF, Trarbach EB, Latronico AC: Genetics basis for GnRH-dependent pubertal disorders in humans. Mol Cell Endocrinol 2010, 324:30-38,

50. Ubuka T, Bentley GE: Identification, localization, and regulation of passerine GnRH-I messenger RNA. J Endocrinol 2009, 201:81-87.

51. Sutter NB, Bustamante CD, Chase K, Gray MM, Zhao K, Zhu L, Padhukasahasram B, Karlins E, Davis S, Jones PG, Quignon P, Johnson GS, Parker HG, Fretwell N, Mosher DS, Lawler DF, Satyaraj E, Nordborg M, Lark KG, Wayne RK, Ostrander EA: A single IGF1 allele is a major determinant of small size in dogs. Science 2007, 316:112-115.

52. Reutens AT, Begley CG: Endophilin-1: a multifunctional protein. Int J Biochem Cell Biol 2002, 34:1173-1177.

53. Anggono V, Robinson PJ: Syndapin I and endophilin I bind overlapping proline-rich regions of dynamin I: role in synaptic vesicle endocytosis. J Neurochem 2007, 102:931-943.

54. Hirayama S, Bajari TM, Nimpf J, Schneider WJ: Receptor-mediated chicken oocyte growth: differential expression of endophilin isoforms in developing follicles. Biol Reprod 2003, 68:1850-1860.

doi:10.1186/1471-2156-12-33

Cite this article as: Xu et al:: Genetic effects of polymorphisms in candidate genes and the QTL region on chicken age at first egg. BMC Genetics 2011 12:33.

\section{Submit your next manuscript to BioMed Central} and take full advantage of:

- Convenient online submission

- Thorough peer review

- No space constraints or color figure charges

- Immediate publication on acceptance

- Inclusion in PubMed, CAS, Scopus and Google Scholar

- Research which is freely available for redistribution

Submit your manuscript at www.biomedcentral.com/submit
(Ciomed Central 